ment, gauges, electronic controls, nuclear components and industrial television.

\section{Science for Survival}

Dr. I. H. Usmani's presidential address, "Science for Survival", to the fifteenth annual science conference of the Pakistan Association for the Advancement of Scienco, opens with a plea for the development of a scientific rather than an emotional approach to Pakistan's problems and a reminder that science itself reveals the beauty, the symmetry and the mystery of matter and life (Pp. 26. Karachi: I. H. Usmani, Pakistan Atomic Energy Commission, 1963). Its application has a long history, although something like 90 per cent of the science and technology now at our disposal is the product of this century. Reviewing the present needs and opportunities in Pakistan, he pleads for more generous help from the more advanced nations. However, while he is justly critical of present expenditure on armaments and on space research projects, he is not entirely fair to the efforts which some countries are already making in technical assistance. 'The major part of his address is an admirable survey of the situation in Pakistan and of the practical tasks confronting the scientist and administrator and concludes with a summary of the recommendations of the Scientific Commission appointed in 1958, on which little action has as yet been taken.

\section{Science in Parliament}

In answer to a question in the House of Commons on May 28, the Parliamentary Secretary for Science, Mr. D. Freeth, said that the United States Public Health Service had given the figure of $£ 543,000$ for expenditure by its National Institutes of Health on research projects in the United Kingdom in their fiscal year 1962. The Research Councils employed 518 persons on geological research, an increase of 23 per cent in the past 5 years. The Department of Industrial and Scientific Research had increased its research work at the National Engineering Laboratory on industrial machine design, its support of research associations and grants to research workers, as woll as instituting development contracts. The report of the Fielden Committee on engineering design was expected shortly and $\mathrm{Mr}$. Freeth also referred to the grant of $£ 140,000$ to the Institute for Advanced Studies in Engineering Sciences at the University of Birmingham for research into an interdisciplinary approach to machine design.

The Royal College of Science and Technology, Glasgow

ON May 31, in a written answer in the House of Commons, the Chief Secretary to the Treasury, Mr. J. A. Boyd-Carpenter, stated that the University Grants Cornmittee had now formally advised him that in view of the importance of an early decision in relation to the plans of the Royal College of Science and Technology, Glasgow, for academic development, particularly in industrial and social studies, and the desirability of more university places in Scotland, the College should be granted full university status. The Robbins Committee had been consulted and seen no objoction. He had accordingly accepted this advice and had authorized the University Grants Committeo to inform the College that the way was clear for it to prepare a draft charter.

\section{Research in the Social Sciences}

IN answer to a Parliamentary question in the House of Commons on May 30, Mr. R. A. Butler said that the Government had decided to set up an independent Committeo of Enquiry into the whole question of rescarch in the social sciences. Lord Heyworth had agreed to become chairman of this Committee. Pressed as to why this Committee had not been appointed by the Ministor for Science, Mr. Butler merely said that the social sciences were rathor broader than Lord Hailsham's responsibilities and that he himself had been asked to take the responsi- bility for the social sciences. Mr. Butler undertook to convey to Lord Heyworth the sense of urgency apparent in the House.

\section{The Fleming Memorial Fund for Medical Research}

The Trustees of the Fleming Memorial Fund for Medical Research have announced a grant of $£ 50,000$ to the Imperial College of Science and Technology, Univer. sity of London, for its Department of Biochemistry, headed by Prof. E. B. Chain. This - the Fund's sixteenth grant to assist basic medical research at home and overseas since Decermber 1961-brings the total of the Fund's grants to more than $£ 260,000$. The Fund's 1961-62 appeal raised monies to a present value of $£ 495,000$. The grant will enable two main lines of investigation to bo pioneered further, under Prof. Chain's direction: $(a)$ the study of regulatory mechanisms, with special reference to the mode of action of insulin and thyroxin; $(b)$ the study of metabolic reactions in nervous tissue, central and peripheral, with special reference to amino-acid-carbohydrate interrelations. Work in these two fields could result, in due courso, in important additions to knowledge of motabolic and mental disorders.

\section{Production and Use of Protein-rich Foods in Develop- ing Areas}

The Food and Agriculture Organization of the United Nations and the United Nations Children's Fund is organizing in Rome, during October 21-25, a meeting with the food industries in order to stimulate the production and use of protein-rich foods in developing areas. From the investigations mado during the past ten years it has bocome clear that protein deficiency of the diet, particularly of young children, is one of the major nutritional problems in many of the developing regions of the world. In addition to the development of agriculture to produce more protein-rich foods of conventional kinds, intensive efforts are being made to utilize currently unused sources of proteins for human feeding. The two major types of such proteins at present are fish-flour and flours obtaincd from oil seeds, such as groundnuts, sesame, cotton-seed, soyabean, etc., after the extraction of the oil. Considerable progress has already been achieved in producing high-protein foods from such materials for human feeding, but the production is satisfying only a fraction of the need. The major reasons are the difficulties involved in the expanded production, introduction and marketing of such new foods. It is the purpose of this meeting to discuss these problems with represcntatives of the food industries with the hope that it will cnhance progress and lead to the quicker availability of commercially produced low-cost protein-rich foods. In addition to personnel of the United Nations Agencies, some governmental specialists and those from rescarch institutions will be invited to participatc. However, the majority of those attonding are expected to represent industry from various countries coneorned with the production of these new types of foods.

\section{Ethiopian Prize Trust for National and African Awards}

The establishment of an Ethiopian Prize Trust for National and African Awards has recently been announced. Five National Awards, each of a value not less than 7,000 Eth. dollars $(£ 1,000)$, will be made each year for outstanding achievements in: $(a)$ agriculture; $(b)$ industry; (c) Amharic literature; $(d)$ fine arts; and $(e)$ humanitarian activities. Ten four-year undorgraduate scholarships for study in Ethiopia and at least two two-year graduate fellowships for study abroad will also be made available annually to Ethiopian students of exceptional promiso. An award of a value not less than 20,000 Eth. dollars $(£ 2,850)$ will be given to individuals of any nationality who make outstanding contributions to Ethiopian studios. An award of a value not less than 70,000 Eth. dollars $(£ 10,000)$ will be given to an individual or a non-govern- 